\title{
The Effect of Marketing Mix on Satisfaction and Its Impact on Hotel Customer Loyalty in Pekanbaru-Riau
}

\author{
Arizal.N1, Wita Dwika Listihana ${ }^{2}$, Nofrizal ${ }^{3}$ \\ ${ }^{1}$ University of LancangKuning, Pekanbaru, Indonesia, $\bowtie$ (e-mail) arizall_n@yahoo.com \\ ${ }^{2}$ University of LancangKuning, Pekanbaru, Indonesia, $\square$ (e-mail) witadwikalistihana62@gmail.com \\ ${ }^{3}$ University of LancangKuning, Pekanbaru, Indonesia, $\bowtie$ (e-mail) nofrizalfe@unilak.ac.id
}

\begin{abstract}
The purpose of this study to test and analyze empirically the influence of Quality Service to satisfaction and its impact on customer loyalty hotel in Pekanbaru City. Organization and Service Company in its operation is determined is the quality of the services it produces where the quality of these services include several dimensions such as the physical form owned by the organization or service, how empathy of the employees, responsive and also the extent to which the reliability of the service provider. The quality of this service will affect the user satisfaction of the service and this satisfaction will have an impact on the loyalty of the user. From this research can see how the influence of the quality of service to satisfaction and its impact on the loyalty of hotel customers in Pekanbaru City. The results of this study indicate that there is influence of marketing mix to satisfaction and its impact on customer loyalty of hotel in Pekanbaru-Riau
\end{abstract}

Keywords: quality of service, satisfaction and loyalty

\section{Introduction}

The tourism sector is one of the sectors developed by the Indonesian government so that it will be able to contribute better to the national income. Various efforts were made to support the sector in the form of facilities. The government also gives freedom to the private sector to be able to provide accommodation to visit tourists who will enjoy the various beauty and panorama of Indonesia. This accommodation is in the form of hotels, restaurants and other handicrafts as souvenirs. Tourists who come to Indonesia from year-to-year shows an increasing growth in which in 2015 the number of tourists is 10.41 million people and rose in 2016 of 11.52 million people or $10.69 \%$ the number of tourists is 47,000 people and rose on year 2016 of 7,772 people into a cumulative total of 54,772 people or $16.54 \%$.

Riau Province is one of the provinces in Indonesia that become tourist interest, where the data obtained from Riau Province in the number 2016 explained that the number of foreign visitors who visit in 2015 as many as 54,437 people. Most of the foreign tourists entering Pekanbaru is $51.09 \%$ or 27,810 people. Most of the tourists that is $76.51 \%$ comes from ASEAN countries and $23.49 \%$ comes from other countries. The number of hotels obtained from Riau Province in 2016 figures is the number of hotels in 2015 as many as 405 units spread across the Regency or city in Riau Province. The largest number of hotels in the city of Pekanbaru yaiut 105 units or about $25.93 \%$. The number of rooms and beds as many as 13,604 rooms and 21,618 beds. In Pekanbaru City there are 6,082 rooms (44,71\%) and 9,142 beds $(42,29 \%)$.

Based on the number of existing hotels in Pekanbaru city of 105 units, this indicates that the hotel will be increasingly tight in competing to attract the interest of tourists or from other guests such as business and pedagamgan. The hotel will be required to be able to provide various facilities and facilities required by consumers or customers who can satisfy. The most important thing is that the hotel must be able to compete in attracting customers through service. 
Hotels should be able to provide satisfaction to customers through various variables of the marketing mix. For that the hotel should be able to create a variety of marketing mix with surplus compared with competitors and exceed customer expectations.

\section{Methods}

This research type is descriptive method (survey) with quantitative research design, that is research not only give description about phenomenon but also explain, test hypothesis and get meaning from fact which exists. The population used in this study is all hotel customers in Pekanbaru City. Due to the large population then in this study were taken samples. The sample size is based on the size of the quota sample that is taken as many as 120 respondents The determination of the number of samples taken. To complete the research the variables studied in this study can be seen below: from 3 hotels in Pekanbaru City, namely Hotel Pangeran, Hotel Mutiara and Hotel Primer.

\begin{tabular}{|c|c|}
\hline 1. & Product \\
\hline 2. & Price \\
\hline 3. & Place \\
\hline 4. & Promotion \\
\hline 5 & Process \\
\hline 6 & People \\
\hline 7 & Phisical Evidence \\
\hline 8. & satisfaction \\
\hline 9. & Loyalty \\
\hline
\end{tabular}

Data analysis technique used in this research is to use the method of analysis Questionnaire used to collect data from the variables studied using Liker scale for each answer scored the values used are criteria strongly agree (5), up to strongly disagree (1). Testing the influence of variables hypothesized in this study using structural equation model (Warp.PLs.5) Consideration using this model because of its ability to measure the construct through its indicators as well as analyzing the indicator variable, latent variable and error measurement. Complete structural model in this research.

\section{Results and Discussion}

1. Respondent Characteristics

Characteristics Respondents for gender showed that male respondents were 51 people or $42.50 \%$ while women were 69 people or $57.50 \%$. This indicates that most of hotel service user respondents in this research are women. Based on the age of the respondents are aged under 25 years that is equal to 78 people or $65 \%$, and in part respondents are aged $36-45$ years as many as 4 people or $3.33 \%$. Other respondents are $26-36$ people as many as 27 people or $22.50 \%$ and those aged over 45 years are as many as 11 people or $9.17 \%$. Based on level of education is educated on level SMU that is as many as 67 people or $53.83 \%$, while the educated graduate there are as many as 35 people or $28.33 \%$. While other respondents are level of education on diploma as much as 1 person or $0.83 \%$. Besides, there are 16 people or $13.33 \%$ of respondents who have S2 degree and 2 or $1.67 \%$ who have S3 education. Based on the large status of respondents is the status of not married as many as 77 people or $64.17 \%$, while the status of marriage as many as 43 people or $35.83 \%$. Based on the type of work large respondents are having a job as a student as much as 44 people or $36.67 \%$, while working as entrepreneur is as many as 20 people or $16.67 \%$. Other types of occupations of the respondents are as private employees as many as 17 people or $14.17 \%$, as civil servants as many as 14 people or $11.67 \%$ and work as other fields as many as 25 or $20.83 \%$. 


\section{Marketing Mix}

Marketing mix consisting of 7P shows respondents response about products at hotel in Pekanbaru. The results showed that for the indicator of the product in accordance with the standard set average of respondents is 4.3 in the category of very good. In the indicator of how the quality of service products provided by the hotel, average respondents is 4.1 is in good category, while for hotel brand indicator average response of respondents is equal to 4.28 that is in very good category. It can be concluded that the implementation of the mix for the dimensions of the product of the responses of respondents is very good. At the price indicates that for the indicator of affordable tariff averaging the response of respondents is 3.72 that is in good category. In the indicator of how the tariff in accordance with the quality of services provided by the hotel, average respondents is 3.77 is on the good category, while for the indicator of tariff determination in accordance with the average competitor is 3.92 in the good category. It can be concluded that the implementation of the mix for the dimension of price or tariff set by hotel the response of respondents is good. In the location of the study showed that for the indicator of easily accessible location the average respondent's response is 8.34 that is in good category. In the strategic location indicator of hotel, the average respondent response is 4.13 is in good category, while for hotel location indicator that can support the activity of respondent, the result is the average of respondent response 3,87 that is in good category. It can be concluded that the implementation of the mix for the dimension of price or tariff set by hotel the response of respondents is good. On the promotion shows that for the average advertising indicators respondents 4.44 is on the category very good. In the indicator of the implementation of personal selling at the hotel, the average respondents is 4.33 is on very good category, while for indicators of sales promotion average of respondents is 4.3 is on the category very good. It can be concluded that the implementation of the marketing mix for the promotion dimension set by the respondents is very good.

In the process shows that for the process indicator can to use services in hotel average respondents respondent is 4.24 that is in very good category. In the implementation indicators for the requirements of the use of hotel services, the average respondents is 4.21 is on very good category, while for the indicator of the process of checking and check out the average respondent is 4.27 that is in very good category. It can be concluded that the implementation of the marketing mix for service process dimensions set by the respondent's response to the hotel is very good. In the service of the research service indicates that for the indicator that the employees really understand the duty of respondent average respondent is 4.25 that is in very good category. On employee skill indicator at hotel, average respondent is 4.18 is in good category, while for indicator of knowledge of employee knowledge average is 4.12 that is in good category. It can be concluded that the implementation of the mix of marketing for the dimensions of people (employees) owned by the hotel the response of respondents is good. In the physical environment indicates that for the average indicator of advertising responses of respondents is 4.22 is on very good category. In the interior indicator of the hotel, the average response of respondents is 4.23 is on very good category, while for the indicator how the spatial owned hotel respondents average of 4.27 is on the category very well. It can be concluded that the implementation of the influence mix for the physical environment dimension of the hotel from the responses of respondents is very good.

\section{Customer satisfaction}

Based on the results of the responses of respondents is very good. It means what is expected by the customer about the quality of hotel services is very in line with expectations. How the determination of rates set by the hotel whether it is in line with customer expectations, from the results of research shows the average response of respondents is 4.27 is on good category. Here are the responses of respondents about the location of the hotel, then the average response of respondents is 4.28 and this is on the category very good. It means hotel location is in accordance with the expectations of customers. Implementation of promotion by four-star hotel in Pekanbaru City, the results of the responses of respondents is an average of 3.86 or in either category. This means that the promotion done by the hotel by the customer is good. Physical environment is an existing environment in hotels 
or facilities provided by the hotel so as to improve the quality of service. From the results of research based on the responses of respondents about the physical environment is an average of 4.84 is on the category very well. This means that the physical environment of the hotel according to the responses of respondents is already very good and enjoyed in accordance with expectations.

The results of research on the performance of hotel employees in providing services to customers, from the responses of respondents is an average of 3.98 is on good category. This reflects that the service provided by hotel employees to customers is good. The result of the research concerning the employee's attention to the hotel customers from the responses of respondents is an average of 3.97 is on good category. This reflects that employee attention to hotel users is good. The results of research on employees who are responsive and always helpful, users, from the results of respondents is an average of 4.06 is on either category. This reflects that the responsiveness of employees to the hotel users and always help shown by hotel employees is good. Furthermore, how the guarantee given by the hotel to its customers based on the responses of respondents is an average of 4.05 which means there is a good category. This shows that the guarantee given by the hotel to its customers is already in line with the expectations of its users.

4. Loyalty

The result of the hotel user's response to his loyalty is from the indicator by giving recommendations to others. Where respondents average on the value of 3.83, namely on the category of good category. Furthermore, on the dimension where the customer also take the product line generated by the hotel, the response of respondents is an average of 3.63 is in the category agree or good. This means that most hotel users agree to use other services offered by the hotel. Furthermore, the level of customer loyalty from the indictor that the customer will not move to the competitor despite the offer, then the average respondent's response is 2.87 that is in the less agree or less good category. This means that most hotel users disagree that they are not moving to another hotel if there is an offer from a competitor. Besides how the level of customer loyalty from the indictor that the hotel users also provide feedback and advice to the hotel for progress. Customer, then the average respondent's response is 3.93 that is in either category or agree. This means that most hotel users agree to provide feedback and suggestions to the hotel for the progress and service of the hotel.

5. The Influence of Marketing Mix on Satisfaction and Its Impact On Loyalty

After analyzing the data descriptively on marketing mix variables and their dimensions to the satisfaction and impact variable at the level of customer loyalty of hotel in Pekanbaru City. The following will be analyzed for these variables are quantitatively quantified. Data analysis in this research is done through two stages that is first step is to conduct evaluation analysis to model of measurement (outer model) by test validity and reliability for each research variable result can be seen table 1.

From the table above we can know that all variables and indicators are valid which means that all theinstruments used in this research are true and trusted, both from product, promotion, tariff, location, process, employees and physical environment, the level of satisfaction and loyalty is valid.As for the reliability test is how the level of consistency of measurement tools used in this study can be seen from the following table 2 .

From the table above can be seen that all the research instruments are product, promotion, Price, location, process, employees and physical environment, the level of satisfaction and loyalty is reliable. This means that the measuring instrument used is conserved. ' 
Table 1. Outer Model Validity

\begin{tabular}{|c|c|c|c|c|}
\hline & Indicator & Loading Factor & Ave & Criteria \\
\hline \multirow[t]{3}{*}{ Product } & $\operatorname{Pr} 1$ & 0.825 & \multirow{3}{*}{0.613} & \multirow{3}{*}{ Valid } \\
\hline & $\operatorname{Pr} 2$ & 0.806 & & \\
\hline & $\operatorname{Pr} 2$ & 0.713 & & \\
\hline \multirow[t]{3}{*}{ Promotion } & Pm1 & 0.835 & \multirow{3}{*}{0.648} & \multirow{3}{*}{ Valid } \\
\hline & Pm2 & 0.884 & & \\
\hline & Pm3 & 0.683 & & \\
\hline \multirow[t]{3}{*}{ Price } & Hg1 & 0.852 & \multirow{3}{*}{0.661} & \multirow{3}{*}{ Valid } \\
\hline & $\mathrm{Hg} 2$ & 0.764 & & \\
\hline & $\mathrm{Hg} 3$ & 0.821 & & \\
\hline \multirow[t]{3}{*}{ Location } & Lk1 & 0.887 & \multirow{3}{*}{0.753} & \multirow{3}{*}{ Valid } \\
\hline & Lk2 & 0.899 & & \\
\hline & Lk3 & 0.816 & & \\
\hline \multirow[t]{3}{*}{ Process } & Ps1 & 0.882 & \multirow{3}{*}{0.702} & \multirow{3}{*}{ Valid } \\
\hline & Ps2 & 0.857 & & \\
\hline & Ps3 & 0.769 & & \\
\hline \multirow[t]{3}{*}{ People } & $\mathrm{J} 1$ & 0.834 & \multirow{3}{*}{0.741} & \multirow{3}{*}{ Valid } \\
\hline & $\mathrm{J} 2$ & 0.89 & & \\
\hline & $\mathrm{J} 3$ & 0.857 & & \\
\hline \multirow[t]{3}{*}{ Physical Evidence } & Pp1 & 0.874 & \multirow{3}{*}{0.759} & \multirow{3}{*}{ Valid } \\
\hline & Pp2 & 0.899 & & \\
\hline & Pp3 & 0.84 & & \\
\hline \multirow[t]{9}{*}{ Costumers Satisfaction } & Kp1 & 0.769 & \multirow{9}{*}{0.54} & \multirow{9}{*}{$\begin{array}{c}\text { less } \\
\text { Valid }\end{array}$} \\
\hline & Kp2 & 0.703 & & \\
\hline & Kp3 & 0.64 & & \\
\hline & Kp4 & 0.673 & & \\
\hline & Kp5 & 0.733 & & \\
\hline & Kp6 & 0.794 & & \\
\hline & Kp7 & 0.765 & & \\
\hline & Kp8 & 0.739 & & \\
\hline & Kp9 & 0.782 & & \\
\hline
\end{tabular}

Table 2. Outer Model Reliability

\begin{tabular}{llll}
\hline & Composite reliability & Cronbach's alpha & Criteria \\
\hline Product & 0.825 & 0.682 & Reliabel \\
\hline Promotion & 0.845 & 0.723 & Reliabel \\
\hline Price & 0.854 & 0.743 & Reliabel \\
\hline Location & 0.901 & 0.835 & Reliabel \\
\hline Process & 0.876 & 0.786 & Reliabel \\
\hline People & 0,895 & 0,825 & Reliabel \\
\hline Physical Evidence & 0,904 & 0,841 & Reliabel \\
\hline Costumers Satisfaction & 0,913 & 0,893 & Reliabel \\
\hline Loyalty & 0,848 & 0,756 & Reliabel \\
\hline
\end{tabular}

Source: Data Process, 2018

To see how the structure model in this study can be seen on the model structure of the following research see figure 1 below. 


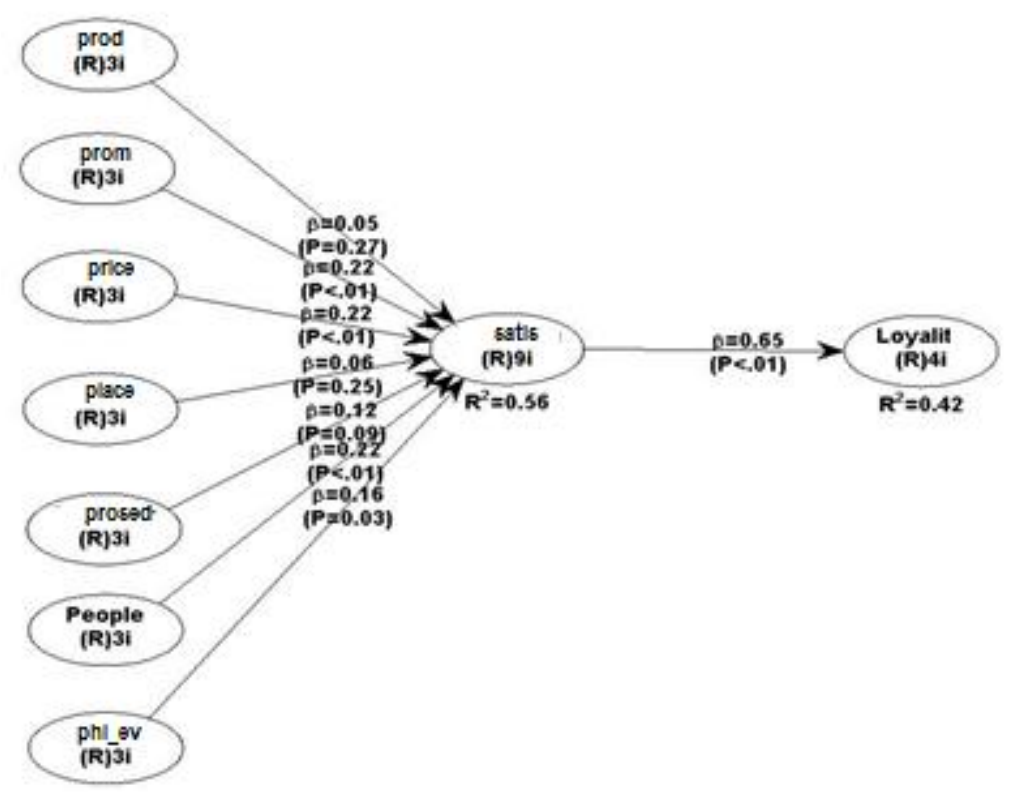

Figure 1. Structural Model of Research

From the structural model above can be known how the level of influence of each marketing mix variables to variable satisfaction and also can show the level of the influence itself whether it is significant or not.In product dimension, research result show that there is a positive relationship between product with satisfaction level equal to 0,05 meaning if there is improvement in product, then level of customer satisfaction positively will increase. The effect of product dimension on satisfaction is 0.27 which means insignificant. For the promotion dimension carried out by the hotel, the research results show there is a positive relationship between the promotion with a satisfaction level of 0.22 which means if promotion is increased, then the level of satisfaction will positivelyincrease. The effect of promotion on satisfaction is 0.01 which means significant, at a $1 \%$ error rate. For the tariff or price dimension set by the hotel, the result of the research indicates that there is a positive correlation between the tariff or the price with the satisfaction level equal to 0,22 which means if the price is held change, food positively will change in the satisfaction level. The effect of price on satisfaction is 0.01 which means significant, at a $1 \%$ error rate.

For the location dimension, the result of the research shows that there is a positive correlation between the location and the satisfaction level of 0.06 which means if the location of the hotel is improved, the level of satisfaction will positively increase. The influence of location on satisfaction is 0.22 which means insignificant. For process and procedure dimensions, the result of the research shows that there is a positive correlation between process and procedure to satisfaction level equal to 0.12 meaning that if improvement of process and procedure is increased, then level of satisfaction will positively increase. The effect of empathy on satisfaction is 0.09 which means significant, at a $10 \%$ error rate. For the dimensions of employees owned by the hotel, the results showed there is a positive relationship between the ability of employees with a satisfaction level of 0.22 which means that if the ability of employees improved, then the level of satisfaction will positively increase. The influence of employee's ability to satisfaction is 0.01 which means significant, at $1 \%$ error rate. For the physical environment dimension owned by the hotel, the result of the research shows that there is a positive correlation between the physical environment with the satisfaction level of 0.16 , which means that if the physical environment is improved, the positive level of satisfaction will increase.

The effect of physical environment on satisfaction is 0.03 which means significant, at the error rate of $5 \%$. The result of determination coefficient is 0.56 , it shows that the satisfaction level of the customer of four star hotel in Pekanbaru City is formed from the marketing mix consisting of product dimension, promotion, tariff, location, process, employee and physical environment, 0.56 above. While the rest is formed by other factors from outside this study. The next result is how the 
relationship between the level of satisfaction with the level of loyalty of four-star hotel users in Pekanbaru City is to show there is a positive relationship between the variable satisfaction with loyalty variable of 0.65 which means if the level of satisfaction can be increased, then the loyalty level of the hotel positive will increase. While the influence of the level of satisfaction with loyalty less than 0.01 means significant at the error rate of $1 \%$. The result of measurement of coefficient of determination of loyalty is 0.42 , this shows that influence from satisfaction level to loyalty is equal to 0.42 , while the rest is influenced by other factor.

\section{Discussion}

The success of the service in achieving its goal is highly dependent on the various dimensions of the marketing mix it provides to each customer. The marketing mix describes the various variables of the various targeting programs aimed at satisfying the satisfaction and the loyalty of the customers.Likewise with the hotel industry which is a business engaged in services. Where the marketing mix formed by the hotel will be able to affect the satisfaction in the service user, besides that the buck will also be able to influence the loyalty to the customer.

From the seven dimensions of the formation of variable satisfaction, it can be seen that the production, promotion, price, location, procedure, people and physical evidences that there are four variables that significantly influence promotion, price, people and physical evidence. While the rest have no significant effect. Then also can be known variable of promotion, place and people berkonstibusi biggest. This shows that the marketing of hotel services in Pekanbaru City is more caused by promotional factors, prices and also people and physical evidence. As according to Kim, WG, Ma, X., \& Kim, DJ (2006) that The results indicate that Chinese hotels are less likely to rely on hotel information needs and online security as they become more experienced Internet users. Later it was also submitted by Mucai, GP, Mbaeh, EK, \& Noor, AI (2013) that the marketing process has no significant influence on customer satisfaction in the non star classified hotels in the hospitality industry. This is slightly different, but overall marketing mix has a significant effect on satisfaction. It was also presented by Al Muala, A., \& Al Qurneh, M. (2012) that show that product and place are significant on destination loyalty. While, price, personnel and process not sig nificant on destination loyalty, and for show that product, place, price, personnel and process significant impact on tourist satisfaction. In addition, show that the tourist satisfaction mediates the relationship between Marketing Mix and loyalty. In addition, also delivered by Yoo, M., \&Bai, B. (2013) that customer loyalty to better understand its evolution and development in the hospitality industry. According to Sarker, M. A. H., Aimin, W., \& Begum, S. (2012) that the six out of seven marketing mix elements were positively related to tourists 'satisfaction but price imposed by the authority is not satisfactory to the visitors'.

Then the satisfaction of hotel customers also affect the loyalty of hotel customers in Pekanbaru city. This right is in line with Widianti, H., \&Utami, E. U. S. (2016) results that customer satisfaction service, switching and voice effect on loyalty. Also the results of research Saputro, D. A., Hufron, M., \&Slamet, A. R. (2017) that the variable customer satisfaction, customer trust and Switching Barriers have an effect by simultan to loyalityOgan shop Malang. Variable customer satisfaction, customer trust and Switching Barriers have an effect by partial to loyalityOgan shop Malang.

According to (Rachmawati \& Azis, 2017)the marketing mix of services is composed of 7P's, namely: product (product), price (place), place, promotion, people or participant, process services), and physical evidence (physical evidence). From the research results Influence of promotion dimensions, tariff that set, process, employees and physical hotel there are significant. Equivalent product dimension and location have no significant effect to satisfaction. Furthermore, the determinant between product, promotion, set tariff, location, process, employees and environment of hotel physics to satisfaction is equal to 0.56(Achmad Rinaldo Fernandes, A., \& Solimun, 2018). This means that the hotel user satisfaction is 0.56 is from the above dimensions, while the remaining 0.44 is from other factors outside this study. While the influence of satisfaction on loyalty is significant and 
the effect is 0.65 . This means that the loyalty level of four-star hotel in Pekanbaru City by the satisfaction of 0.65 .

The results of this study are in line with research from (Alfiando, Y., \& Darmansyah, 2014)entitled The Effect of Service Marketing Mix On Consumer satisfaction at Grace Horizon Hotel Bengkulu shows that the marketing mix at the hotel has been running well. Consumer satisfaction on the services of the hotel is quite satisfied / good. Simultaneously (together) service marketing mix dimension significantly influence consumer satisfaction, partially, only place dimension (place) which has no significant effect to customer satisfaction.

According (Veva, 2015) entitled The Effect of Marketing Mix On Consumer Satisfaction At Resty Hotel Tower of Pekanbaru shows the result of research that marketing done by the hotel has satisfied the customer, while the marketing mix has a significant influence to customer satisfaction. According result from (Normasari, Kumadji, \& Kusumawati, 2013)states that the results of statistical analysis show the quality of service, customer satisfaction, and loyalty have a positive and significant relationship.

\section{Conclusions}

From the results of the above research it can be taken some conclusions as follows; Response of respondents in this case four-star hotel user in Pekaanbaru City to dimension of mix of budget which consist of product, promotion, set tariff, location, process, employees and environment of hotel phissik good enough, good and very good.The influence of promotional dimensions, defined tariffs, processes, employees and the environment of the hotel phissik is significant, while the product and location are insignificant. The determinant of physical evidence, reliability, responsiveness, empathy and assurance of satisfaction is 0.56 . This means that hotel user satisfaction is formed by 0.56 from the marketing mix dimension.The effect of satisfaction on loyalty is significant and the effect is 0.65 . This means that the rate of hotel user loyalty is influenced by the satisfaction level of 0.65 . The relationship between satisfaction and loyalty from the results of research is 0.65 . this means that the relationship between satisfaction and loyalty is positive.

\section{Acknowledgments}

This research was supported/partially supported by UPPM Faculty Economic and LPPM University of LancangKuningPekanbaru. We thank our colleagues fromMrs.WitaDwikaListihana and Nofrizal as member of this Research who provided insight and expertise that greatly assisted the research, although they may not agree with all of the interpretations/conclusions of this paper.

\section{References}

Achmad Rinaldo Fernandes, A., \& Solimun, S. (2018). The mediation effect of customer satisfaction in relationship between service quality, service orientation and marketing mix strategy to customer loyalty. Journal of Management Development, 00-00.

Alfiando, Y., \& Darmansyah, D. (2014). Pengaruh bauran pemasaran jasa terhadap kepuasan konsumen pada grage horizon hotel bengkulu. (Doctoral Dissertation Universitas Bengkulu).

Al Muala, A., \& Al Qurneh, M. (2012). Assessing the relationship between marketing mix and loyalty through tourists satisfaction in Jordan curative tourism. American Academic \& Scholarly Research Journal, 4(2), 1.

Kim, W. G., Ma, X., \& Kim, D. J. (2006). Determinants of Chinese hotel customers'e-satisfaction and purchase intentions. Tourism Management, 27(5), 890-900.

Mucai, G. P., Mbaeh, E. K., \& Noor, A. I. (2013). Extended Marketing Mix and Customer's Satisfaction in Classified Non-Star Hotels in Meru Municipality Kenya. International Review of Management and Business Research, 2(3), 691-696.

Normasari, S., Kumadji, S., \& Kusumawati, A. (2013). Pengaruh Kualitas Pelayanan Terhadap 
Kepuasan Pelanggan, Citra Perusahaan Dan Loyalitas Pelanggan. Jurnal Administrasi Bisnis (JAB), 6(2), 1-9.

Rachmawati, D., \& Azis, R. (2017). Analisis tingkat kepuasan konsumen terhadap kualitas pelayanan hotel ( Studi Kasus pada Hotel Gumaya di Semarang ). Jurnal Manajemen, 1-8.

Saputro, D. A., Hufron, M., \& Slamet, A. R. (2017). pengaruh kepuasan pelanggan, kepercayaan pelanggan dan switching barriers terhadap loyalitas pelanggan (Studi Kasus Pada Toko Ogan Malang). Jurnal Ilmiah Riset Manajemen, 6(02).

Sarker, M. A. H., Aimin, W., \& Begum, S. (2012). Investigating the impact of marketing mix elements on tourists 'satisfaction: An empirical study on east lake. European journal of business and management, 4(7), 273-282.

Veva, D. G. (2015). Pengaruh Bauran Pemasaran terhadap Kepuasan Konsumen pada Hotel Resty Menara Pekanbaru. Jurnal Online Mahasiswa (JOM) Bidang Ilmu Sosial Dan Ilmu Politik, 2(2), 1-9.

Widianti, H., \&Utami, E. U. S. (2016).pengaruh core qualit, relational quality, perceived value, customer satisfaction, service switching dan voice terhadap loyality pada kantor konsultan pajak husni \& mulyadi consulting. Foku sBisnis: Media Pengkajian Manajemen dan Akuntansi, 15(2).

Yoo, M., \&Bai, B. (2013). Customer loyalty marketing research: A comparative approach between hospitality and business journals. International Journal of Hospitality Management, 33, 166-177. 